\title{
Studies on Dextran-degrading Enzymes. Solubilization of the Surface-bound Dextranase of Cytophaga john- sonii by Proteolytic Enzymes, Snake Venoms and Detergents
}

\author{
By J.-C. JANSON \\ Institute of Biochemistry, University of Uppsala, 751 2 I Uppsala 1, Sweden
}

(Received 12 September 1973; revised 25 November 1974)

SUMMARY

The effect of various solubilizing agents on the release of the dextranase from whole Cytophaga bacteria or washed envelopes is described. Among the proteolytic enzymes tested, only $\alpha$-chymotrypsin solubilized the dextranase very efficiently with retained enzymic activity even after prolonged exposure. Among the snake venoms tested, that of Hemachatus haemachates showed the highest selectivity and efficiency. Non-ionic detergents with hydrophilic-lipophilic balance values of about 13 to 15 also effectively and selectively solubilized the membrane-bound enzyme. Organic solvents, urea, guanidine hydrochloride, glycine, chaotropic ions, $\mathrm{pH}$ variations and mechanical disruption (including osmotic shock) were ineffective.

\section{INTRODUCTION}

Janson (1975) showed that the dextranase [ $\alpha$-D-(I,6)-glucan 6-D-glucanohydrolase; EC. 3.2. I. II] of a strain of Cytophaga johnsonii (Stanier, 1947) was located on the envelope surface. Few systematic studies have been published on the solubilization of membranebound enzymes of bacteria in general and of myxobacteria in particular, or on tests of a variety of solubilizing agents with this strain. The isolation and characterization of the dextranase and of the intracellular $\alpha$-glucosidase will be published elsewhere.

\section{METHODS}

Growth of bacteria. The bacteria were grown in 60 and 6001 batches in mantled stainless steel cultivation vessels at the Institute of Microbiology, Royal Agricultural College, Uppsala, Sweden, and at the Biotechnical Section of the Bacteriological Department, Karolinska Institutet, Stockholm, Sweden, respectively. The growth medium was as described by Janson (1975) with the exception that $0.05 \%$ yeast extract was added and that the $\mathrm{pH}$ was adjusted to $6 \cdot 5$. The bacteria were grown at 29 to $30{ }^{\circ} \mathrm{C}$ for approximately $24 \mathrm{~h}$ with continuous stirring. The medium was aerated at a rate of $\mathrm{I} \cdot 5 \mathrm{l}$ air $/ \mathrm{l}$ medium $/ \mathrm{min}$, with a silicone antifoam agent added when required. The $\mathrm{pH}$ of the medium was recorded throughout the growth experiment, and decreased to a final value of 5.9 . The bacteria were harvested after cooling with a refrigerated Sharples supercentrifuge or a De Laval BRPX-207 separator. One 1 medium provided approx. Io $g$ wet wt bacteria. The packed cells thus obtained could be stored at $-35{ }^{\circ} \mathrm{C}$ in sealed containers without appreciable loss of dextranase activity.

Preparation of enzymically active envelopes. One part frozen bacteria was thawed and thoroughly suspended in one part $0.05 \mathrm{M}$-tris- $\mathrm{HCl}$ buffer $\mathrm{pH} 7.5$ to which had been added $10 \mathrm{mg}$ DNAase (Sigma DN-IOO)/ml. The bacteria were disintegrated by pressing (French \& 
Milner, I955) in $85 \mathrm{ml}$ portions. The press was pre-cooled in ice. After incubation at $40{ }^{\circ} \mathrm{C}$ for $30 \mathrm{~min}$ (to hydrolyse DNA, as shown by a considerable decrease in viscosity), the homogenate was diluted with a half volume of buffer and was centrifuged in a Spinco preparative ultracentrifuge for $2 \mathrm{~h}$ at $42000 \mathrm{~g}$ using the ' 20 rotor'. The sediment, freed from a very small amount of densely packed undisrupted bacteria at the bottom, was washed four times with three volumes of the same buffer. The washed envelopes were kept at $-35{ }^{\circ} \mathrm{C}$ until used.

Solubilization with enzymes and snake venoms. Trypsin, $\alpha$-chymotrypsin and aminopeptidase were from Worthington, Freehold, New Jersey, U.S.A., papain and carboxypeptidase from Sigma, and lysozyme was from Miles-Seravac, Maidenhead, Berkshire. Bacillus subtilis proteinase was from Novo, Copenhagen, Denmark. Penicillium notatum proteinase (Makonnen \& Porath, I968) and Arthrobacter proteinase (von Hofsten, van Kley \& Eaker, 1965) were gifts from Dr G. Pettersson and Dr B. von Hofsten, respectively. The snake venoms (Table 3) were all purchased from Ross Allens Reptile Institute, Silver Springs, Florida, U.S.A., and bee venom from Koch-Light. Preliminary experiments were performed with $5 \mathrm{ml}$ portions of envelope suspension in $0.1 \mathrm{M}$-tris- $\mathrm{HCl}$ buffer $\mathrm{pH} 7.6$ incubated at $40^{\circ} \mathrm{C}$ in Lusteroide centrifuge tubes. In the enzyme and the snake venom experiments the envelope concentrations were 160 and $75 \mathrm{mg}$ dry $\mathrm{wt} / \mathrm{ml}$, respectively. The enzyme concentration was $\mathrm{I} \mathrm{mg} / \mathrm{ml}$ and the incubation time $2 \mathrm{~h}$. The venom concentration was $2 \mathrm{mg} / \mathrm{ml}$ and the incubation time $75 \mathrm{~min}$. The incubation mixtures were cooled in ice and centrifuged at $30000 \mathrm{~g}$ for $\mathrm{I} h$ in a refrigerated high speed centrifuge (Sorvall RC2-B). Dextranase activity was assayed in the initial suspension, in the ice-cold incubation mixture and in the supernatant. $\alpha$-Chymotrypsin and Hemachatus haemachates venom were chosen to test the effect of various parameters such as $\mathrm{pH}$, time, and concentrations of solubilizing agent and envelopes in detail.

Solubilization with surface active agents. The Tween, Brij and Myrj detergents are products of Atlas Chemical Industries, Wilmington, Delaware, U.S.A. and were a gift from Kemiintressen AB, Stockholm, Sweden. The Triton detergents are products of Rohm and Haas, Philadelphia, Pennsylvania, U.S.A., and were a gift from Chemacryl AB, Stockholm, Sweden. The Berol detergents were a gift from Modo-Kemi AB, Stenungsund, Sweden. Sodium dodecyl sulphate was obtained from Schuchardt, Munich, Germany. Cetyltrimethylammonium bromide and cetylpyridinium chloride were purchased from Kebo, Stockholm, Sweden. Preliminary experiments were performed with 26 different detergents (Table 2). Whole bacteria were treated with $\mathrm{I} \%(\mathrm{w} / \mathrm{v})$ detergent in $0.05 \mathrm{M}$-tris- $\mathrm{HCl}$ buffer $\mathrm{pH} 7.5$ at $30{ }^{\circ} \mathrm{C}$ for $20 \mathrm{~min}$ in conical flasks on a rotatory shaker. Dextranase activity was measured in the initial suspension, in the incubation mixture and in the supernatant obtained after centrifuging at $30000 \mathrm{~g}$ for $\mathrm{I} h$. Triton $\mathrm{X}-\mathrm{I} 00$ and Tween $20 \mathrm{SD}$ were subjected to more detailed studies concerning the effect of $\mathrm{pH}$, ionic strength, time, temperature, and detergent and EDTA concentrations.

Effect of organic solvents. $n$-Butanol (reagent grade) was used at concentrations from I to $40 \%(\mathrm{v} / \mathrm{v})$ at $4{ }^{\circ} \mathrm{C}$. Acetone powder was made by mixing one part of ice-cold envelope suspension with three parts of cold $\left(-35^{\circ} \mathrm{C}\right)$ acetone (reagent grade). The precipitate was washed with the cold acetone on a Büchner funnel and allowed to dry in $\imath$ vacuum dessicator containing paraffin flakes. Dextranase was extracted from the dry powder with tris buffer, $0.05 \mathrm{M}, \mathrm{pH} 7.5$.

Effect of chaotropic ions, urea, glycine and hydrogen ion concentration. Reagent grade $\mathrm{KSCN}, \mathrm{KI}, \mathrm{NaClO}_{4}, \mathrm{NaNO}_{3}, \mathrm{Cl}_{3} \mathrm{C} \mathrm{COONa}$, urea and glycine were used at $\mathrm{I}$ and $2 \mathrm{M}$ concentrations in $0 . \mathrm{I}$ M-tris- $\mathrm{HCl} \mathrm{pH} 8.0$. Buffers $(\mathrm{O} \cdot \mathrm{I}$ and I M) were prepared in the $\mathrm{pH}$ range 
3 to I I. Glycine- $\mathrm{HCl}$ was used at $\mathrm{pH}_{3} \cdot 0$, acetate at $\mathrm{pH} 4 \cdot 0$ and $\mathrm{pH} 5 \cdot 0$, phosphate at $\mathrm{pH} 6 \cdot 0$ and $\mathrm{pH} 7 \cdot 0$, tris- $\mathrm{HCl}$ at $\mathrm{pH} 8 \cdot 0$, and finally glycine- $\mathrm{NaOH}$ at $\mathrm{pH} 9 \cdot 0, \mathrm{pH} 10 \cdot 0$ and $\mathrm{pH} 10 \cdot 6$. The cell envelope concentration was $35 \mathrm{mg}$ dry $\mathrm{wt} / \mathrm{ml}$. The solutions were mixed in test tubes on a rotatory mixer at $4{ }^{\circ} \mathrm{C}$ and at room temperature for $\mathrm{I} h$. After centrifugation at $30000 \mathrm{~g}$ for $\mathrm{I} \mathrm{h}$, dextranase was assayed in the supernatants after dialysis against $0.05 \mathrm{M}$ tris- $\mathrm{HCl}$ buffer $\mathrm{pH} 8 \cdot 0$.

Effect of mechanical disruption and osmotic shock (cold shock). The following mechanical disintegration methods were tested: sonic oscillation with a Branson V-1 2 sonifier, pressing in a French press (French \& Milner, 1955) and the use of $0.1 \mathrm{~mm}$ glass beads in an Eppenbach colloid mill. In attempts to release the dextranase by osmotic shock (cold shock) the procedure described by Nossal \& Heppel (1966) was used.

Enzyme assay. Dextranase activity was assayed as described by Janson (1975).

\section{RESULTS}

Preliminary analysis revealed that envelopes which had been extensively washed with buffer solutions and distilled water and lyophilized, contained $55 \%(\mathrm{w} / \mathrm{w})$ protein, $40 \%$ lipid (material extractable in acetone-alcohol, 50:50, v/v), and 5\% carbohydrate (hexose + hexosamine). This result resembles the compositions of membranes from erythrocytes, microsomes and mitochondria rather than that of envelopes of other myxobacteria. For example, the composition of the envelopes of Cytophaga fermentans is: protein 75 to $85 \%$ $(\mathrm{w} / \mathrm{w}$ ), lipid I $\%$, and carbohydrate $7 \%$ (Collins, I 964 ). This discrepancy in composition might be due to differences in both treatment of envelopes and in the analytical methods used for the estimates. To discover a procedure for the complete solubilization of the dextranase from the envelope membrane material, substances known to weaken bonds of various kind were used.

\section{Electrostatic bonds}

The coulombic bonds are sensitive to changes in hydrogen ion concentration, to high ionic strengths and to the presence of substances with high dielectric constants. Incubation of envelopes in up to I $\mathrm{M}$ buffers at $\mathrm{pH}$ values from 3 to I I and in the presence of $2 \mathrm{M}$-glycine at $\mathrm{pH} 6.0$ did not liberate soluble dextranase.

\section{Hydrophobic bonds}

Most of the proteins in membranes are bound to phospholipids by hydrophobic bonds. According to the lipid-globular protein mosaic model of membrane structure (Singer \& Nicolson, 1972) the proteins are partially imbedded in, and partially protruding from, the membrane. To effect solubilization of such proteins one has to disrupt the lipid-protein bonds with acetone, $n$-butanol and natural or synthetic detergents. Drying with acetone often facilitates extraction of enzymes from dispersions of whole tissues or cytoplasmic particles. However, attempts to obtain a dextranase-active acetone powder from the envelopes failed. $n$-Butanol has unique properties in dissociating lipid-protein and lipoprotein complexes (Morton, 1955). Single-phase extraction with different concentrations as well as two-phase extraction with $40 \% n$-butanol, the former method at different $\mathrm{pH}$ values and for various periods of time, failed to release dextranase, but often resulted in up to $50 \%$ loss of enzyme activity. Two-phase extraction destroyed dextranase activity. Urea and guanidine$\mathrm{HCl}$ weaken hydrophobic bonds by increasing the solubility in water of the hydrophobic amino acid residues (Nozaki \& Tanford, I963; Hatefi \& Hanstein, I969). Incubation with different concentrations of these chemicals at $\mathrm{pH} 6.0$ and $\mathrm{pH} 8.5$ did not solubilize the 
Table I. The effect of various detergents on the solubilization of dextranase from washed whole bacteria

The results are given as percentages of the activity of the control suspension.

\begin{tabular}{|c|c|c|c|c|}
\hline \multirow[b]{2}{*}{ Detergent } & \multirow[b]{2}{*}{ Chemical composition } & \multirow[b]{2}{*}{$\begin{array}{l}\text { HLB } \\
\text { value }\end{array}$} & \multicolumn{2}{|c|}{$\begin{array}{c}\text { Dextranase activity } \\
(\%)\end{array}$} \\
\hline & & & Incubate & $\begin{array}{l}\text { Super- } \\
\text { natant }\end{array}$ \\
\hline Tween 20 & Polyoxyethylene sorbitan monolaurate & $16 \cdot 7$ & 100 & 68 \\
\hline 40 & Polyoxyethylene sorbitan monopalmitate & $15 \cdot 6$ & IOO & 55 \\
\hline 80 & Polyoxyethylene sorbitan monooleate & $15 \cdot 0$ & IOO & 66 \\
\hline 60 & Polyoxyethylene sorbitan monostearate & $\mathrm{I} 4.9$ & 100 & 63 \\
\hline 85 & Polyoxyethylene sorbitan trioleate & $11 \cdot 0$ & 100 & 6 \\
\hline 65 & Polyoxyethylene sorbitan tristearate & $10 \cdot 5$ & 100 & 45 \\
\hline $8 \mathrm{I}$ & Polyoxyethylene sorbitan monooleate & $10 \cdot 0$ & 100 & 4 \\
\hline Triton $X-45$ & Octylphenoxy (polyethoxyethanol) ${ }_{5}$ & 10.4 & 100 & 16 \\
\hline X-I I4 & Octylphenoxy (polyethyoxyethanol) ${ }_{7-8}$ & I 2 & 100 & 76 \\
\hline$X-100$ & Octylphenoxy (polyethoxyethanol) $)_{9-10}$ & 14 & IOO & 102 \\
\hline $\mathrm{X}-\mathrm{IO} 2$ & Octylphenoxy (polyethoxyethanol) $)_{12-13}$ & $14 \cdot 6$ & 100 & 64 \\
\hline$X-405$ & Octylphenoxy (polyethoxyethanol) ${ }_{40}$ & $17 \cdot 9$ & IOO & 20 \\
\hline $\mathrm{N}-\mathrm{IOI}$ & Nonylphenoxy (polyethoxy) $)_{10}$ ethanol & $13 \cdot 4$ & 100 & 88 \\
\hline Berol 072 & Polyoxyethylene mixed fatty alcohol ether & I I & 100 & 90 \\
\hline 085 & Polyoxyethylene fatty alcohol ether & 13.5 & 100 & 92 \\
\hline 267 & Nonylphenoxypolyethoxyethanol & $12 \cdot 3$ & 100 & 21 \\
\hline 296 & Nonylphenoxypolyethoxyethanol & $15 \cdot 2$ & IOO & 82 \\
\hline EMU-09 & Nonylphenoxypolyethoxyethanol & 13.6 & 100 & 98 \\
\hline Brij 30 & (Polyoxyethylene) ${ }_{4}$ lauryl ether & $9 \cdot 7$ & 100 & o \\
\hline 35 & (Polyoxyethylene) $_{23}$ lauryl ether & $16 \cdot 9$ & 100 & 29 \\
\hline Myrj 5i & Polyoxyethylene stearate & $16 \cdot 0$ & IOO & 17 \\
\hline 53 & Polyoxyethylene stearate & 17.9 & IOO & 40 \\
\hline Deoxycholate & Sodium deoxycholate & 一 & 95 & 62 \\
\hline SDS & Sodium dodecyl sulphate & 40 & 84 & 84 \\
\hline $\mathrm{CPC}$ & Cetylpyridinium chloride & - & 32 & o \\
\hline CTB & Cetyltrimethylammonium bromide & - & 28 & o \\
\hline
\end{tabular}

dextranase but at high concentrations destroyed it. Chaotropic ions such as trichloroacetate, perchlorate, thiocyanate and iodide are also known to increase the solubility in water of various non-electrolytes by weakening the strength of hydrophobic interactions, e.g. in biomembranes (Hanstein, Davis \& Hatefi, 1971). However, none of the chaotropic ions tested solubilized dextranase activity although at high concentrations it was destroyed. Natural detergents, such as sodium deoxycholate and sodium cholate, as well as synthetic cationic, anionic and non-ionic surface active agents, may all disrupt lipid-protein complexes or combine with lipoproteins or with proteins which are hydrophobic because of the presence of hydrophobic residues on their surface. Successful extractions of membrane enzymes with such compounds have been reported (Holowach et al. 1966; Neeman, Kahane \& Razin, I97I; Kagawa, 1972).

The results of solubilization experiments with several detergents are presented (Table I). The non-ionic surfactants are more suitable for the extraction of the dextranase than the ionic. The best results were obtained with alkyl aryl polyether alcohols and lauryl ether alcohols having hydrophilic-lipophilic balance (HLB) values around 13 to I4. This often corresponded to about Io mol ethyleneoxide in the polyethylene glycol chains. Sodium dodecyl sulphate, which completely solubilized the envelopes giving clear solutions, could not be 
Table 2. The effect of $\mathrm{pH}$, buffer type and detergent concentration on the solubilization of dextranase from whole bacteria by Tween $20 S D$

Solubilized dextranase activities are expressed as percentages of the activity of the control suspension, and detergent concentrations as $\%(\mathrm{w} / \mathrm{v})$. The suspensions contained $34 \mathrm{mg} \mathrm{dry} \mathrm{wt} / \mathrm{ml}$, and incubation was at $30^{\circ} \mathrm{C}$ for $30 \mathrm{~min}$ on a rotary shaker.

\begin{tabular}{|c|c|c|c|c|c|}
\hline \multirow[b]{2}{*}{ Buffer } & \multicolumn{2}{|c|}{$\mathrm{pH}$} & \multicolumn{3}{|c|}{$\begin{array}{l}\text { Dextranase activity }(\%) \text { for } \\
\text { detergent concentrations of: }\end{array}$} \\
\hline & Initial & Final & $0.5 \%$ & $1.0 \%$ & $2.0 \%$ \\
\hline Potassium phosphate $(0.05 \mathrm{M})$ & $\begin{array}{l}6 \cdot 0 \\
7 \cdot 0 \\
8 \cdot 0\end{array}$ & $\begin{array}{l}6.03 \\
6.95 \\
7.65\end{array}$ & $\begin{array}{l}19 \\
34 \\
47\end{array}$ & $\begin{array}{l}38 \\
50 \\
60\end{array}$ & $\begin{array}{l}49 \\
6 I \\
65\end{array}$ \\
\hline Tris- $\mathrm{HCl}(0.05 \mathrm{M})$ & $\begin{array}{l}8 \cdot 0 \\
9 \cdot 0\end{array}$ & $\begin{array}{l}7 \cdot 80 \\
8 \cdot 62\end{array}$ & $\begin{array}{l}40 \\
35\end{array}$ & $\begin{array}{l}49 \\
39\end{array}$ & $\begin{array}{l}52 \\
44\end{array}$ \\
\hline Glycine- $\mathrm{NaOH}(0.05 \mathrm{M})$ & $\begin{array}{r}9 \cdot 0 \\
10 \cdot 0\end{array}$ & $\begin{array}{l}7 \cdot 47 \\
9 \cdot 80\end{array}$ & $\begin{array}{l}71 \\
29\end{array}$ & $\begin{array}{l}85 \\
30\end{array}$ & $\begin{array}{l}87 \\
30\end{array}$ \\
\hline Carbonate-bicarbonate $(0.05 \mathrm{M})$ & 10.0 & $9 \cdot 16$ & 20 & 26 & 30 \\
\hline
\end{tabular}

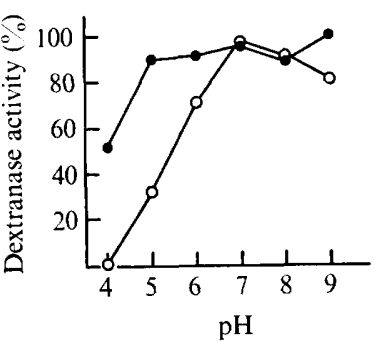

Fig. I

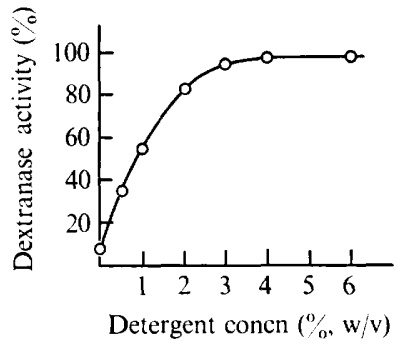

Fig. 2

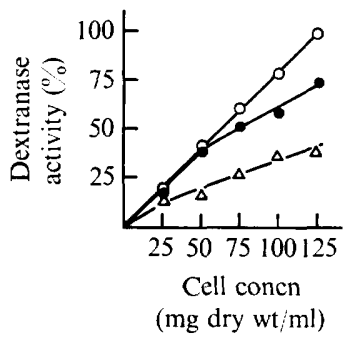

Fig. 3

Fig. I. The effect of $\mathrm{pH}$ on the solubilization by Triton X-I00 of dextranase from washed whole bacteria. Enzyme activities are expressed as percentages of maximal. Detergent concentration $2 \%$ $(\mathrm{w} / \mathrm{v})$ in $0.05 \mathrm{M}$ buffers: acetate at $\mathrm{pH}_{4} .0$ and $\mathrm{pH} 5.0$, phosphate at $\mathrm{pH} 6.0$ and $\mathrm{pH} 7.0$, and tris$\mathrm{HCl}$ at $\mathrm{pH} 8.0$ and $\mathrm{pH} 9.0$. Incubation $2 \mathrm{~h}$ at $5{ }^{\circ} \mathrm{C}$ on a rotatory shaker. Activity in incubate; $O$, activity in supernatant.

Fig. 2. The effect of detergent concentration on the solubilization by Triton X-100 of dextranase from washed envelopes. The envelope concentration was $20 \mathrm{~g}$ wet $\mathrm{wt} / \mathrm{I} 00 \mathrm{ml}$ suspension. Incubation took place on a rotating mixer at $5^{\circ} \mathrm{C}$ for $90 \mathrm{~min}$. The buffer used was $0.1 \mathrm{M}$-potassium phosphate pH 7.5. Solubilization effects are expressed as percentages of incubate activity.

Fig. 3. Solubilization of dextranase from bacteria by $2 \%(w / v)$ Triton $X-100$ at room temperature as a function of bacterial concentration after incubation for 60,15 and $5 \mathrm{~min}$. Potassium phosphate

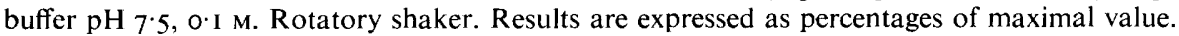

used owing to the rapid decrease in enzyme activity on storage. Tween 20 SD (specially deodorized polyoxyethylene sorbitan monolaurate) has the advantage of being both mild to enzyme activity and having a low $E_{2 \times 0}$. Efforts were therefore made to optimize the conditions for solubilization of the dextranase with this detergent. The best effect with Tween $20 \mathrm{SD}$ was obtained when the envelopes or whole bacteria were extracted with $0.05 \mathrm{M}$-glycine$\mathrm{NaOH}$ buffer $\mathrm{pH} 9.0$ containing I to $2 \%(\mathrm{w} / \mathrm{v})$ detergent, at $30{ }^{\circ} \mathrm{C}$ for $30 \mathrm{~min}$ (Table 2 ). The most efficient detergent, Triton X-100, was chosen for a more detailed study. The following parameters were examined: $\mathrm{pH}$, detergent concentration, ionic strength, EDTA concentration, incubation time, and temperature. The best solubilization was achieved at $\mathrm{pH}$ values between 7 and 9 (Fig. I), and at concentrations of Triton X-Ioo around $2 \%(w / v)$ or higher 
(Fig. 2). Contrary to the report of Tzagoloff \& Penefsky (1971) no significant variation in solubilization effect was found when different buffers at concentrations from 0.02 to I $\mathrm{M}$ were used. Metal ions such as $\mathrm{Mg}^{2+}$ are believed to take part in the structural organization of membranes (Razin, I 972). Thus I I \% of the proteins in Acholeplasma laidlawii membranes were solubilized by treatment with EDTA (Neeman et al. 197I). However, no dextranase activity was solubilized from $C$. johnsonii membranes with up to $0.05 \mathrm{M}$-EDTA at $\mathrm{pH} 8.0$ and $9^{\circ} 0$. The period of incubation with Triton X-100 required for maximum solubilization varied both with temperature and concentration of envelopes/bacteria. At $30^{\circ} \mathrm{C}$ the maximum value was reached in a few minutes on a shaking water bath. Even at room temperature $\left(18{ }^{\circ} \mathrm{C}\right)$ the envelope concentration markedly influenced the solubilization time (Fig. 3).

\section{Mechanical disruption and osmotic shock}

All the disintegration techniques tested caused disruption and diminished the size of the membrane particles to a greater or lesser extent. Sonic oscillation produced homogenates which were extremely difficult to centrifuge. The maroon-coloured membrane particles formed density gradients in the centrifuge tubes, and measurements of dextranase on samples withdrawn from increasing depths of the supernatants showed a clear correlation between the enzyme activity and membrane concentration (colour). Thus the apparent solubilization by mechanical disruption could always be ascribed to inadequate centrifugation. Likewise, osmotic shock and cold shock performed as described by Nossal \& Heppel ( I966) did not release any dextranase activity which could not be attributed to the presence of membranes.

\section{Solubilization with enzymes and snake venoms}

Snake venoms are rich sources of hydrolytic enzymes and seven of nine snake venoms released the dextranase activity from the envelopes more or less completely (Table 3 ). One difference in the mechanism was observed: venoms of members of the order Elapidae did not attack the rest of the envelopes as much as venoms of members of the orders Crotalidae and Viperidae. To investigate the cause of the solubilization with the snake venoms, they were all submitted to fractionation by gel filtration on Sephadex G-75. The fractions obtained were then assayed for dextranase releasing, proteolytic (caseinolytic) and esterase ( $\beta$-naphthylacetate) activities. Without exception, the two former activities coincided in the chromatograms. The elapid venoms examined contained very small amounts of proteolytic activity, but nevertheless they very effectively solubilized the dextranase, especially the venom of Hemachatus haemachates. Further fractionation on Sephadex G-I0o and hydroxyapatite of the Hemachatus venom showed that the dextranase-releasing activity was coupled with neither the caseinolytic nor the $\beta$-naphthylacetase (esterase) activities. Phospholipase activity was not assayed. Fryklund \& Eaker (I973) showed that the venom of Hemachatus haemachates contains $25 \%$ 'lytic factor' (mol. wt 7000) and a phospholipase with a molecular weight of I 4000 .

All of the proteolytic enzymes listed in Table 3, which were able to liberate the dextranase, solubilized up to $75 \%$ of the envelope. $\alpha$-Chymotrypsin was chosen for further studies because of its effectiveness, its properties of restoring dextranase activity, its availability and purity, and the ease with which it could be withdrawn in the subsequent methods of separation. To find the optimum conditions for preparative solubilization of the dextranase by $\alpha$-chymotrypsin, the effect of $\mathrm{pH}$ (Fig. 4) and chymotrypsin concentration (Fig. 5) was studied. Owing to the high stability of the dextranase activity in the presence of $\alpha$ chymotrypsin, an incubation temperature of up to $40{ }^{\circ} \mathrm{C}$ could be used for several hours. 
Table 3. Ability of various snake venoms and enzymes to remove the dextranase from washed envelopes of $C$. johnsonii

Portions $(5 \mathrm{ml})$ of a wall suspension in $0.1 \mathrm{M}$-tris- $\mathrm{HCl}$ buffer $\mathrm{pH} 7.6$ were incubated at $40{ }^{\circ} \mathrm{C}$ in Lustroide centrifuge tubes, cooled in ice and centrifuged at $30000 \mathrm{~g}$ for $\mathrm{I} h$ in a refrigerated high-speed centrifuge. Dextranase was assayed for in the initial suspension and in the ice-cooled incubates and supernatants.

\begin{tabular}{|c|c|c|c|}
\hline \multirow[b]{3}{*}{ Reagent } & \multicolumn{3}{|c|}{ Dextranase activity } \\
\hline & \multirow{2}{*}{$\begin{array}{l}\text { In incubate } \\
\text { Percentage of } \\
\text { initial value }\end{array}$} & \multicolumn{2}{|c|}{ In supernatant } \\
\hline & & $\begin{array}{l}\text { Percentage of } \\
\text { that in incubate }\end{array}$ & $\begin{array}{l}\text { Percentage of } \\
\text { initial value }\end{array}$ \\
\hline \multicolumn{4}{|l|}{ Snake venoms* } \\
\hline Agkistrodon piscivorus & 107 & 96 & 103 \\
\hline Bitis arietans & 108 & 98 & 106 \\
\hline Bothrops atrox & I 10 & 94 & 104 \\
\hline Crotalus adamanteus & 102 & 22 & 22 \\
\hline Dendroaspis polylepis & 107 & 92 & 99 \\
\hline Hemachatus haemachates & 106 & 90 & 95 \\
\hline Naja nigricollis & 106 & 92 & 98 \\
\hline Trimeresurus okinavensis & IOI & 63 & 64 \\
\hline Vipera russellii & 104 & 25 & 26 \\
\hline Bee venom & 93 & 7 & $6 \cdot 5$ \\
\hline \multicolumn{4}{|l|}{ Enzymes $\dagger$} \\
\hline Lipase (pancreas) & 98 & 6 & 6 \\
\hline Lipase (wheat germ) & 99 & 3 & 3 \\
\hline Lipase (microbiol.) & 97 & 7 & $6 \cdot 5$ \\
\hline Trypsin & $8 \mathrm{I}$ & 13 & II \\
\hline Alpha-chymotrypsin & ror & 96 & 97 \\
\hline Papain & 103 & 74 & 76 \\
\hline Aminopeptidase & 95 & 5 & 5 \\
\hline Carboxypeptidase & 98 & 3 & 3 \\
\hline Proteinase (B. subtilis) & 49 & 72 & 35 \\
\hline Proteinase (Penicillium) & $\begin{array}{r}49 \\
103\end{array}$ & 97 & 100 \\
\hline Proteinase (Arthrobacter) & 43 & 81 & 35 \\
\hline Lysozyme & $\begin{array}{l}45 \\
93\end{array}$ & 8 & $7 \cdot 5$ \\
\hline
\end{tabular}

* Wall concentration: $75 \mathrm{mg}$ dry $\mathrm{wt} / \mathrm{ml}$. Venom concentration: $2 \mathrm{mg} / \mathrm{ml}$. Incubation time: $75 \mathrm{~min}$. Venom added as $100 \mu \mathrm{l}$ solution.

+ Wall concentration: $160 \mathrm{mg}$ dry wt/ml. Enzyme concentration: $\mathrm{I} \mathrm{mg} / \mathrm{ml}$. Incubation time: $2 \mathrm{~h}$.

However, since autodigestion of $\alpha$-chymotrypsin is considerable at the $\mathrm{pH}$ used for dextranase solubilization, a temperature of $30{ }^{\circ} \mathrm{C}$ was chosen for most of the experiments.

\section{DISCUSSION}

Several kinds of interactions are possible between an attached enzyme and the membrane. Covalent bonds may be involved, by forming the basis for hydrophobic interactions through residues such as phosphatidylserine or by creating limited but adequate areas of hydrophobic amino acid residues on the surface of the protein molecule. Coulombic bonds may also play a role: for example, magnesium ion is known to aid complex formation between proteins and phospholipids (Penefsky \& Tzagoloff, I97I). A combination of two or more different bond types is of course also possible and may cause problems when trying to interpret the experimental data. The results presented in this paper show that the dextranase of $C$. johnsonii can be classified as an integral protein according to the nomenclature of Singer 


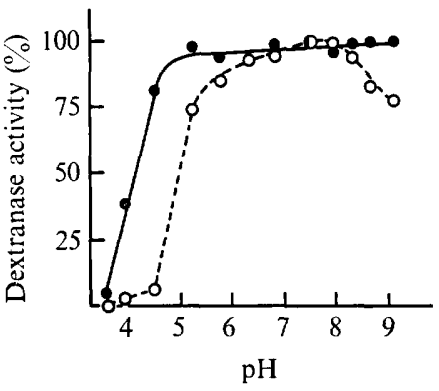

Fig. 4

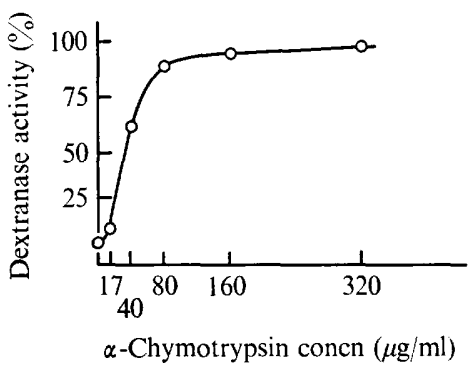

Fig. 5

Fig. 4. Solubilization of dextranase from washed envelopes by $\alpha$-chymotrypsin at various $\mathrm{pH}$ values. The following buffers were used $(0.05 \mathrm{M})$ : acetate, $\mathrm{pH} 3.6$ to 5.2 ; phosphate, $\mathrm{pH} 5.75$ to 6.8 ; tris- $\mathrm{HCl} \mathrm{pH} 7.5$ to $9 \cdot \mathrm{I}$. Chymotrypsin was added at $2.85 \mu \mathrm{g} / \mathrm{mg}$ envelopes. Incubation for $2 \mathrm{~h}$ at $30^{\circ} \mathrm{C}$. Activity of suspensions before addition of $\alpha$-chymotrypsin; $O$, activity in supernatant after incubation and centrifugation. Activities are expressed as percentages of maximal.

Fig. 5. Solubilization of dextranase from washed envelopes at increasing $\alpha$-chymotrypsin concentrations. Envelope concentration $50 \mathrm{mg}$ dry $\mathrm{wt} / \mathrm{ml}$ in $0.05 \mathrm{M}$-tris- $\mathrm{HCl} \mathrm{pH} \mathrm{7.9}$. Incubation $2 \mathrm{~h}$ at $30{ }^{\circ} \mathrm{C}$ in $5 \mathrm{ml}$ Lusteroide centrifuge tubes. Centrifugation $\mathrm{I} \mathrm{h}$ at $37000 \mathrm{~g}$. Dextranase activity was assayed in initial suspension, in the incubate and in the supernatants. The results are expressed as percentages of the activity in the initial suspension. The $\alpha$-chymotrypsin concentrations of $17,40,80$, I 60 and 320 , in $\mu \mathrm{g} / \mathrm{ml}$, correspond to concentrations of $0.34,0 \cdot 8,1 \cdot 6,3.2$ and $6.4 \mu \mathrm{g} / \mathrm{mg}$ envelopes, respectively.

\& Nicolson (1972). Detailed discussion of the possible ways of attachment has to be postponed until more information has been obtained concerning the composition of the detergentsolubilized enzyme. However, from the solubilization with $\alpha$-chymotrypsin and from the fairly narrow specificity of this enzyme, one may conclude (i) that a relatively large part of the enzyme is protruding from the membrane surface, and (ii) that either the link consists of a hydrophobic peptide sequence containing aromatic amino acids giving a hydrophobic bond, or that lipid is covalently bound to, for example, serine (phosphatidyl serine), either located in terminal positions of the dextranase peptide chain proximal to an aromatic amino acid or on some loop containing at least two aromatic amino acids, leucin or threonin in exposed positions on each side.

The invaluable support by Professor Jerker Porath and the skilful technical assistance of Mrs Marie Sundqvist are gratefully acknowledged.

\section{REFERENCES}

Collins, F. M. (1964). Cell wall composition of a marine Cytophaga. Australian Journal of Experimental Biology and Medical Sciences 42, 263-265.

FrenCH, C. S. \& Milner, H. W. (1955). Disintegration of bacteria and small particles by high-pressure extrusion. In Methods in Enzymology, vol. I, pp. 64-67. Edited by S. P. Colowick and N. O. Kaplan. New York: Academic Press.

Fryklund, L. \& Eaker, D. (I973). The complete amino acid sequence of a non-neurotoxic hemolytic protein from the venom of Haemachatus haemachates. Biochemistry I2, 66I-667.

Hanstein, W. G., Davis, K. A. \& Hatefi, Y. (197I). Water structure and the chaotropic properties of haloacetates. Archives of Biochemistry and Biophysics 147, 534-544.

Hatefi, Y. \& Hanstein, W. G. (1969). Solubilization of particulate proteins and nonelectrolytes by chaotropic agents. Proceedings of the National Academy of Sciences of the United States of America 62, II 29-I I 36. 
von Hofsten, B., van Kley, H. \& EAKER, D. (1965). An extracellular proteolytic enzyme from a strain of Arthrobacter. I1. Purification and chemical properties of the enzyme. Biochimica et biophysica acta r10, 585-598.

Holowach, J., Howe, M. C., LaAtsch, R. H. \& MCDougal, D. B., Jun. (I966). Effects of various anions and cations on the release of four dehydrogenases from brain mitochondria by a non-ionic detergent. Biochimica et biophysica acta $1 \mathbf{1 8}, 230-239$.

JANSON, J.-C. ( I975). Studies on dextran-degrading enzymes. Isolation and identification of a dextranaseproducing strain of Cytophaga johnsonii and studies on the formation of surface-bound enzyme. Journal of General Microbiology. 88, 205-208.

KaGAWA, Y. (1972). Reconstitution of oxidative phosphorylation. Biochimica et biophysica acta $\mathbf{2 6 5}, 297-338$.

Makonnen, B. \& Porath, J. (I968). Purification of an extracellular proteinase from Penicillium notatum. European Journal of Biochemistry 6, 425-43I.

Morton, R. K. (1955). Methods of extraction of enzymes from animal tissues. In Methods in Enzymology, vol. 1, pp. 25-5I. Edited by S. P. Colowick and N. O. Kaplan. New York: Academic Press.

Neeman, A., Kahane, I. \& Razin, S. (I97I). Characterization of the mycoplasma membrane proteins. II. Solubilization and enzymic activities of Acholeplasma laidlawii membrane proteins. Biochimica et biophysica acta 249, 169-176.

Nossal, N. G. \& Heppel, L. A. (1966). The release of enzymes by osmotic shock from Escherichia coli in exponential phase. Journal of Biological Chemistry 241, 3055-3062.

NozAKI, Y. \& TANFord, C. (1963). The solubility of amino acids and related compounds in aqueous urea solutions. Journal of Biological Chemistry 238, 4074-408 I.

Penefsky, H. S. \& Tzagoloff, A. ( I971). Extraction of water soluble enzymes and proteins from membranes. In Methods in Enzymology, vol, 22, pp. 204-219. Edited by W. B. Jakoby. New York: Academic Press.

RAZIN, S. (I972). Reconstitution of biological membranes. Biochimica et biophysica acta 265, $241-296$.

Singer, S. J. \& Nicolson, G. L. (1972). The fluid mosaic model of the structure of cell membranes. Science, New York $\mathbf{1 7 5}, 720-731$.

Stanier, R. Y. (1947). Studies on non-fruiting myxobacteria. I. Cytophaga johnsonae, n. sp., a chitindecomposing myxobacterium. Journal of Bacteriology 53, 297-315.

Tzagoloff, A. \& Penefsky, H.S. (1971). Extraction and purification of lipoprotein complexes from membranes. In Methods in Enzymology, vol. 22, pp. 219-230. Edited by W. B. Jakoby. New York: Academic Press. 